Historic, archived document

Do not assume content reflects current scientific knowledge, policies, or practices. 



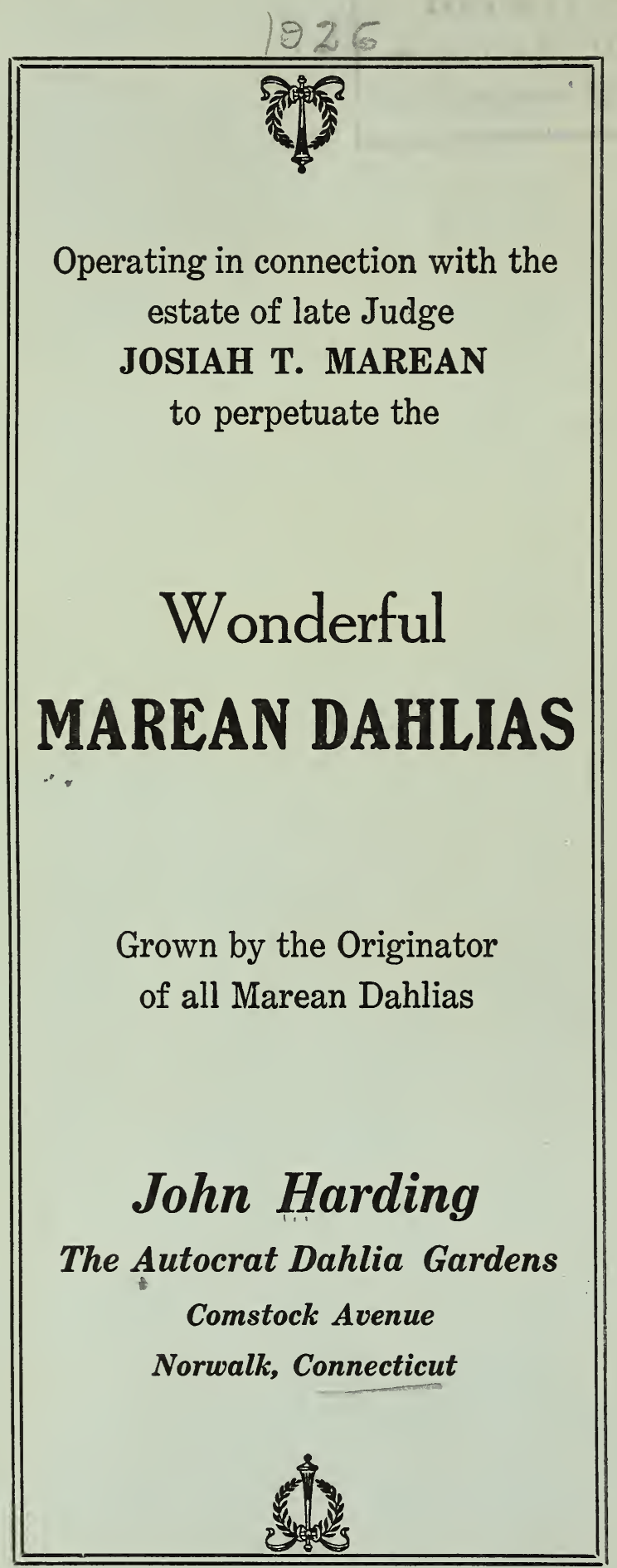




\title{
SPECIAL INFORMATION
}

\section{Visitors Always Welcome to Our Gardens}

\author{
Order Early as orders are filled in \\ rotation, ordering early will \\ insure the reservation of \\ varieties that may \\ be sold out.
}

\section{Terms Cash}

We Guarantee all tubers true to name, and their arrival in good growing condition

Time of Shipment-Tubers will be shipped after April 1st, unless otherwise notified. All retail orders Shipped prepaid. 


\section{Aftarkant}

\section{国ahlitata}

1926

\section{GREETINGS}

U R 1926 Catalog brings greeting to you, and we take this opportunity to express our deep appreciation for your liberal patronage during the past. We trust that you as well as our newer custemers, will enjoy the greatest possible success with your Dahlias this season. We have the best collection of Dahlias in the country. Our root are all field grown without being forced or over-fertilized grown as you grow them. We specialize our own novelties which in our estimation are unexcelled.

Thanking you in advance for any orders you may favor us with, which we assure you will be given our personal attention.

Sincerely Yours, JOHN HARDING 


\section{FAMOUS MAREAN DAHLIAS}

Varieties of superlative and Unrivaled Merit

\section{World's Best Dahlia, Rose Fallon}

And we don't mean May-be!

Decorative. Most wonderful flower of enormous size, held erect on straight, strong stiff stems; this Magnificent bloom is a beautiful color of deep Old Gold of the finest type. This variety created a sensation when exhibited at the 1925 Dahlia show of the A. D. S. and was, without a question, the finest Dahlia in the show. No Dahlia collection should be without this famous novelty.

Tubers $\$ 25.00$, Plants $\$ 12.50$

What the Florists Exchange of October 1925 Said Regarding "Rose Fallon."

John Harding, Norwalk, Conn. who controls all the Judge Marean seedlings not yet disseminated, featured strongly Rose Fallon, easily the most perfectly formed giant Decorative in sight. Two or three flowers in the stand after two and one-half days, were perfect, and had they been in the largest bloom classes, they would have cleaned up everything. Some Dahlia! and not in the least coarse or out of propotion. Grand stems, too, and, as stated, able to stand for days and look one boldly in the eye. The color is deep old gold. It's up to California to surpass Rose Fallon; the rest of the world doesn't count.

\section{LADY JANE.}

H. C. Beautiful large flower carried on strong straight stems; color a most pleasing shade of straw and autumn vigcrous and free bloomer.

Tubers $\$ 10.00$, Plants $\$ 5.00$.

\section{MRS. EDWARDS.}

H. C. Of fine type held on strong straight stems. Color orchid, vigorous grower and free bloomer in allways.

Tubers $\$ 5.00$ 


\section{E. P. O'CONNOR.}

Decorative-Beautiful flower carried on good stems. Color opalescent pink with distinct reverse of purple. Very fine.

Tubers $\$ 5.00$

\section{SULPHUR KING.}

Decorative-A very fine sulphur yellow held erect on strong stems, vigorous grower, large flowers of the finest type. Tubers $\$ 5.00$

\section{MR. R. T. EDWARDS.}

Decorative-One of the finest in our colection; true to type, extra large flower carried on stout stems. Color most pleasing shade of pink with a distinct reverse $\mathrm{plum}$, A very fine Dahlia. Tubers $\$ 10.00$, Plants $\$ 5.00$

\section{MRS. MARY HART.}

Decorative-Large Maroon of good type good stems, large flower. Vigorous grower. Very fine.

Tubers $\$ 5.00$

\section{COPPER KING.}

Decorative-Most wonderful flower of enormous size, held erect on straight, strong stem, this magnificent bloom has tubular petals of copper and yellow with distinct reverse of light red: This is one of our finest creations. A prize winner where shown in 1925 .

Tubers $\$ 10.00$, Plants $\$ 5.00$.

\section{FIRELIGHT.}

Decorative-Beautiful flower carried on stiff stem base yellow, points of petals tipped red. Average height 5 feet. Very fine.

Tubers $\$ 5.00$, Plants $\$ 2.50$.

\section{HARVEST MOON.}

Decorative-Large finely formed flower on a good stem, of a beautiful yellow shade. Average height 5 feet.

Tubers $\$ 5.00$, Plants $\$ 2.50$ 


\section{DARK DAYS.}

Hybrid Cactus-Beautiful flower, carried on stiff stem of beautiful Maroon. free bloomer. Average height $4 \frac{1}{2} \mathrm{Ft}$.

A very

Tubers $\$ 5.00$, Plants $\$ 2.50$

\section{MARION WELLER.}

Decorative-A real fine Dahlia true to type, extra large flower caried on long straight stems. Color of a most pleasing shade of soft pink, very free bloomer. Height about 5 feet Tubers $\$ 5.00$, Plants $\$ 2.50$

\section{POLAR SNOW.}

Decorative-A great pure white Dahlia of the finest type of a giant flower. Stem has a tendency to bend slightly.

Tubers $\$ 5.00$, Plants $\$ 2.50$

\section{THE GIANTESS.}

Decorative-This e n o rmous beautiful flower, of finest form and type, and of a very pleasing shade of amber. Stem has a tendency to bend slightly.

Tubers $\$ 5.00$, Plants $\$ 2.50$

\section{THE BASHFUL GIANT.}

Decorative-Of enormous size, color is apricot with gold shading. Fine for exhibition.

Tubers $\$ 1.00$

\section{THE EMPEROR.}

Decorative-A maroon of the finest type, enormous size and fine stems.

Tubers $\$ 1.50$

\section{THE MERRY WIDOW.}

Decorative-Main color yellow; this is suffused with shade of red. 


\section{CATHERINE WILCOX.}

Decorative-Color white, points of petals tipped cerise. Free bloomer.

Tubers $\$ 1.00$

\section{E. T. BEDFORD.}

Decorative.-Color is purple with a lighter shading of silver. A very free bloomer.

Tubers $\$ 1.00$

\section{JUDGE MAREAN.}

Decorative-Very large flower of perfect type. Color, blending of salmon, gold and pink, free bloomer.

Tubers $\$ 1.00$

\section{LA GROSS BETE.}

Decorative--Large flower of a cerise, self color.

Tubers $\$ 1.00$

\section{PEG OME HEART.}

Peony-Color, old rose with a slight shade of golden yellow,

Tubers $\$ .50$

\section{HERCULES.}

Decorative.-Quilled; of enormous size, cnlor tangerine and $\mathrm{de}$ e $\mathrm{p}$ yellow, reverse of petals tangerine.

Tubers $\$ 1.00$

\section{JUDGE ALTON B. PARKER}

Decorative-Very la rge flower true to form. Color, golden buff Tubers $\$ 1.00$

\section{MABEL THATCHER.}

Decorative-Large flower of pale yellow Fine type. Tubers $\$ 1.00$

MRS. JOHN T. SCHEEPERS.

Decorative-A beautiful flower of a clear yellow, which changes to pink on outer petals

Tubers $\$ 1.00$ 


\section{CHARM.}

Decorative-Color is most pleasing. Combination of burnt orange, shading to yellow.

Tubers $\$ 1.00$

\section{CLEOPATRA.}

Peony-Color is fine shade yellow. reverse of the petals tangerine.

Tubers $\$ .50$

\section{DAKOTA.}

Decorative-Color may be described as being the shade of flame. Strong grower.

Tubers $\$ 1.00$

\section{DIANA.}

Peony-Color of fine scarlet. Flowers of large size.

Tubers $\$ .50$

\section{MRS. I. de VER WARNER.}

Decorative-One of the very best Dahlias, blossom of soft orchid, fine stems and vigorous grower.

Tubers $\$ 2.00$

\section{THE CHOCTAW.}

Peony-Quilled petals. Color is fine pale mahogany.

Tubers $\$ .50$

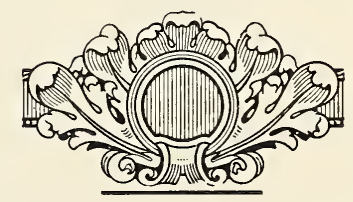




\section{Special Collections.}

\section{Special Offer No. 1}

One of each of any six $\$ 5.00$ Dahlias for $\$ 25$.

\section{Special Offer No. 2}

One each of the following Dahlias for $\$ 10.00$ : The Bashful Giant. The Emperor. The Merry Widow, Catherine Wilcox, Hercules. Judge A. B. Parker, Mabel Thatcher, Mrs. T. John Scheepers. E. T. Bedford. La Gross Bete, Charm and Mrs. I. de Ver Warner.

\section{Special Offer No. 3}

Lost Label Dahlias $\$ 5.00$ Dozen.

We gladly give information for the cultivation of Dahlias on request.

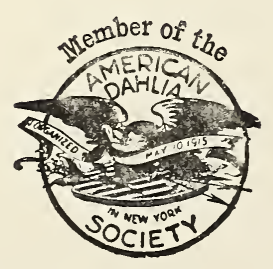




